\title{
Biophysical Studies of Some Bee Products as Radioprotectors
}

2 Shimaa F. Hamieda ${ }^{1}$, Amal I. Hassan ${ }^{2}$, Mona I. Abdou ${ }^{2}$, Wafaa A. Khalil ${ }^{3}$, Kamal N. Abd- El

3 Nour $^{1}$

8 Keywords: Gamma irradiation, Honey, Propolis, UV, FTIR, Minerals, Serum total protein,

$9 \quad$ Albumin and uric acid, Osmotic fragility.

\section{Summary Statement}

11 Assessment of some antioxidant ingredients in honey and propolis. Also, a study on ionizing

12 gamma irradiated rats was done to assess these antioxidants as radioprotectors.

\section{Abstract}

14 The study had been planned to evaluate some antioxidant ingredients in honey and propolis. 15 Also, a study on ionizing gamma irradiated rats was done to assess these antioxidants as 16 radioprotectors. Bioactive ingredients, such as phenols, flavonoids and trace elements, were

17 explored using FTIR, UV-Vis and AAS spectroscopic techniques. Animals were exposed to 18 fractionated gamma radiation doses. Honey, propolis and their combination were administrated 
19 before and during the irradiation period. Serum levels of total protein, albumin and uric acid

20 were estimated. Also, the osmotic fragility of Red Blood Corpuscles (RBCs) membranes and a

21 microscopic examination of blood films were investigated. The analysis demonstrated that the

22 level of phenolic, flavonoid and trace elements are higher in propolis than honey. The levels of

23 total protein and albumin decreased post irradiation while the level of uric acid increased.

24 Likewise, osmotic fragility of RBCs membranes was increased with a sticking forming RBCs

25 aggregation. It had been found that administration of the natural antioxidants induced

26 amelioration in most of the studied parameters. It can be concluded that natural antioxidants

27 produced a modulation against oxidative stress induced by ionizing radiation.

Key words: Gamma irradiation, Honey, Propolis, UV, FTIR, Minerals, serum total protein,

29 albumin and uric acid, Osmotic fragility.

Introduction

Exposure to high doses of ionizing radiation is a rare event. Normally, occupational

32 workers in different fields such as radiologists, industry, mining or research workers have restricted safety precautions. Although in some cases, such as radiation accidents high dose exposure may take place. Radio-protective agents have been widely examined to diminish the oxidative stress initiated by ionizing radiation (Saaya et al. 2017; Smith et al. 2017). Antioxidants are various types of molecules which in low levels fundamentally delays or

37 prevents the oxidation effect of free radicals. (Poljsak et al. 2013). Reactive Oxygen Species (ROS) are produced from normal cellular metabolism (Khan et al. 2018) or as a consequence exposure to some chemicals and/or ionizing radiation (Hosseinimehr, 2010). Oxidative stresses 
41 protect against them. Defense against oxidative stress kept up by utilizing several mechanisms

42 which include antioxidant machinery (El-Missiry et al. 2007). The balanced cellular function is

43 considered as a net result between the produced ROS and the available antioxidant defense

44 mechanisms of the cell (Vit et al. 2010). Consequently, the decrease of cellular antioxidant

45 capacity makes the biological system more susceptible to the malicious impacts of ROS (Birben

46 et al. 2012). A great deal of research has been carried out on the radioprotective action of some

47 synthetic chemical substances as antioxidants. These substances reduce mortality when

48 administered pre exposure to lethal doses of ionizing radiation. But most of them have unwanted

49 side effects that limited their use in medical practice (Cebolla et al. 2017). Using natural products

50 as radioprotectors has several benefits since they are safe with proven therapeutic advantages.

51 The body endogenous defensive system is supported by natural antioxidant compounds provided

52 from nourishment (Nunes et al. 2013). Identification and isolation of antioxidants from natural

53 sources has become an active field of research. Natural antioxidants can be micronutrients

54 (vitamins and trace elements), phenolic compounds (flavonoids, and phenolic acids), nitrogen

55 components (alkaloids, chlorophyll derivatives, amino acids, and amines), or carotenoids.

56 Various types of bees' products, such as honey, pollen, royal gel, honey wax and propolis,

57 have many therapeutic effects including anti-inflammatory, antimicrobial, antioxidant, antitumor,

58 wound healing, and immunemodulatory activities (Boorn et al. 2010).

Honey is a sweet, viscous fluid, elaborated by bees from the nectar of plants and stored in

their combs as food. Honey contains about $0.5 \%$ protein, mainly enzymes and amino acids

61 (Khanal et al. 2010). Honey is readily available, affordable and well accepted by irradiated

62 patients and useful for improving their lives (Orsolic et al. 2010). It is broadly accessible in many

63 communities, although its mechanism of action remains unclear and requires more investigation. 
Propolis is a resinous substance that bees collect from different plants. It is utilized in the

65 construction of, and to seal the cracks in, the beehive. Chemical properties of propolis are not only advantageous to bees but have also pharmacological incentive as a natural mixture (Ali et

67 al. 2010). It is a mixture of resin, basic oils and waxes (Cebolla et al. 2017). More than 200 constituents have been distinguished so far from propolis such as phenolic acids and their esters, caffeic acid and their esters, phenolic aldehydes, flavonoids and ketones; moreover, amino acids, proteins, vitamins (A, C, biotin, $\mathrm{B}_{1}, \mathrm{~B}_{2}$ and $\mathrm{B}_{3}$ ), minerals (calcium, cobalt, copper, iron, magnesium, manganese, phosphorous, potassium, silicon and zinc) (Re et al. 1999). Phenolic compounds are able to scavenge ROS due to their electron donating properties. Also, their antioxidant adequacy relies on the dependability of various systems, besides the number and

74 location of hydroxyl groups. Phenolic compounds exhibited higher antioxidant activity than carotenoids and vitamins (Moreira et al. 2011). Flavones are able to interact with free radicals and with the products of oxidative stress (Moreira et al. 2011; Treml and Smejkal, 2016). Flavonoids (including flavones, flavonols, flavanones and dihydroflavonols) and other phenolics (mainly substituted cinnamic acids and their esters) are the main active constituents of propolis and possess potent antioxidant activities (Almeida et al. 2011). Nutrient antioxidants may act together to reduce free radical's levels (Stan et al. 2012). magnesium are important as cofactors in enzymatic processes, mainly in the structure of the DNA repair system. Some minerals are components of important enzymes such as $\mathrm{Zn}$ for

84 superoxide dismutase and Fe for catalase. Both enzymes protect the cell membranes from 85 oxidative damage. Also Iron is a part of the heme of hemoglobin $(\mathrm{Hb})$, myoglobin and 86 cytochromes (Wołonciej et al. 2016). The high concentration of these mineral elements in 
87 propolis must promote the formation of these enzymes, and as a consequence provide its potent

88 antioxidant capacity (Kocot et al. 2018).

The main goal of this work is to assess the level of some antioxidants constituents in honey

90

91

92

93

and propolis such as phenols and trace elements using different spectroscopic techniques (in vitro study). Also it aimed to examine the extent of the healing ability of honey, propolis and their combination as radioprotectors against ionizing gamma radiation induced oxidative stress damages in male rats (in vivo study).

\section{Materials and methods}

For the in vitro studies, three honey samples $\left(\mathrm{H}_{1}, \mathrm{H}_{2}\right.$ and $\left.\mathrm{H}_{3}\right)$ and two propolis samples $\left(\mathrm{P}_{1}\right.$ and $\mathrm{P}_{2}$ ) were used. $\mathrm{H}_{1}$ was from El-Fayoum area while the other two samples $\mathrm{H}_{2}$ and $\mathrm{H}_{3}$ were from the agricultural research center (Giza-Egypt). $\mathrm{P}_{1}$ was from agriculture research center Giza-Egypt while $\mathrm{P}_{2}$ sample was from a local supermarket.

UV-Visible (UV-Vis) spectroscopic techniques type V-570 (Jasco, Germany) was used for the identification and quantification of phenolic compounds (Stan, 2012). Solutions of honey and propolis samples at a concentration of $0.1 \mathrm{mg} / \mathrm{ml}$, and $10 \mathrm{mg} / \mathrm{ml}$ for honey only, were prepared as follows: $100 \mathrm{mg}$ of honey and propolis are dissolved in $10 \mathrm{ml}$ of distilled water and ethyl alcohol respectively in a ratio $1: 1$, then $1 \mathrm{ml}$ of each solution diluted up to $100 \mathrm{ml}$ of the same solvent. The absorbance between 200-600 nm was measured using the UV-visible spectrophotometer.

Fourier Transform Infrared (FTIR) spectroscopic analysis (Jasco FTIR 300 E, Japan) was chosen to explore the chemical composition of both honey and propolis samples for its straightforwardness and capacity to give fingerprints of the measured samples. Honey and 
109

110

111

112

113

114

115

116

117

118

119

120

121

122

123

124

125

126

127

128

129

130

propolis were dried at $150^{\circ} \mathrm{C}$ then grinded to fine powder, $2 \mathrm{mg}$ of the powder sample was mixed with $200 \mathrm{mg} \mathrm{KBr}$ (FTIR grade) and pressed to make a pellet. The pellet was placed into the sample holder of FTIR to record the spectrum at the range of $4000-400 \mathrm{~cm}^{-1}$.

Atomic absorption spectroscopy (AAS) was used to study the mineral composition of honey and propolis. Six trace elements, Calcium (Ca), Sodium (Na), Iron (Fe), Magnesium (Mg), Potassium (K), and Zinc ( $\mathrm{Zn})$, were determined in three honey and two propolis samples. Samples were dried at $105^{\circ} \mathrm{C}$ and then mineralized by wet digestion method using $\left(\mathrm{HNO}_{3}\right.$ $\mathrm{H}_{2} \mathrm{SO}_{4}$ ). About $0.5 \mathrm{~g}$ of each sample was pre-digested in $4 \mathrm{~mL}$ of $65 \% \mathrm{HNO}_{3}$ (Sigma- Aldrich, Germany) for 24 hours at room temperature, then $4 \mathrm{~mL}$ of $98 \% \mathrm{H}_{2} \mathrm{SO}_{4}$ were added. After cooling, the solution was diluted to $20 \mathrm{~mL}$ with deionized water. Atomic absorption spectrophotometer (Agilent Technologies 200 series AA, USA) was used.

For in vivo studies Cobalt-60 Radiation source (gamma- cell 220), Atomic Energy of Canada Limited, installed at the Middle Eastern Regional Radioisotopes Center for the Arab Countries, Dokki, Cairo was used with an average exposure rate of 3.1 Gy per minute. Experimental rats were subjected to whole body irradiation with gamma fractionated doses of (1Gy / day for 5 continues days) i.e. 5 Gy total dose.

Eighty male albino rats weighing $150-180 \mathrm{~g}$ from the National Research Center (Giza, Egypt) were used. The roles of the Medical Ethical Committee of the National Research Centre were taken in place. Animals were maintained for two weeks under acclimatization conditions of water and diet. They were divided into two main groups, control and irradiated ones. Each group was subdivided into four subgroups $n=10$ each. The four controls were the untreated one, the honey, propolis and their combination treated subgroups. The four irradiated subgroups were the 
131 irradiated one, and the subgroups which irradiated and protected with honey, propolis and their

132 combination.

133 Honey was diluted with water and administered orally to animals at a dose of $250 \mathrm{mg} / \mathrm{kg} / \mathrm{day}$ in

134 a volume of $1 \mathrm{ml} /$ rat for 15 continuous days of the honey sub-control groups. The irradiated 135 subgroups received honey 10 days before irradiation and 5 days during the fractionated 136 irradiation doses.

137 Propolis was extracted using 70\% ethanol; about $10 \mathrm{~g}$ of propolis was dissolved in $100 \mathrm{ml}$ 138 ethanol. The supernatant was separated using filter paper Whatman No (1). The extract was 139 completely evaporated under reduced pressure. Propolis was freshly prepared pre- oral 140 administration in saline at a dose of $90 \mathrm{mg} / \mathrm{kg} /$ day for 15 continuous days of the sub-propolis 141 control group. The irradiated subgroups received propolis 10 days before irradiation and 5 days 142 during the fractionated irradiation doses.

143 Honey and propolis combined subgroups received $250 \mathrm{mg} / \mathrm{kg}$ honey plus $90 \mathrm{mg} / \mathrm{kg}$ propolis 144 /day for continuous 15 days of the combined control sub-group. The irradiated subgroup received 145 the same dose for 10 days before irradiation and 5 days during the fractionated irradiation doses.

146 Blood samples were collected from orbital venous plexuses of the rat eye at different time 147 intervals $1^{\text {st }}, 7^{\text {th }}$ and $14^{\text {th }}$ days post last dose of irradiation. Serum samples were stored at $-20^{\circ} \mathrm{C}$ 148 for the biochemical investigations. Heparinized blood samples were collected for osmotic 149 fragility and blood films were stained for microscopic examination.

150 Biochemical analysis of total protein was determined according to Gornal et al. (1949). 151 Albumin was determined according to Gendler (1984). Uric acid was determined according to 152 Bahram and Trinder (1972). Commercial kits from Biodiagnostic Company, Egypt were used. 
153 The osmotic fragility of Red Blood Corpuscles test is used to detect the fragility of RBCs of

154 different groups. Whole blood was added to varying percent buffered sodium chloride solution of 155 concentrations $0.900,0.765,0.675,0.585,0.540,0.500,0.450,0.400,0.360,0.315,0.270,0.180$,

1560.090 and 0.000 and allowed to incubate at room temperature. The amount of hemolysis is then 157 determined by reading the absorbance of the supernatants at $540 \mathrm{~nm}$ on the spectrophotometer 158 Unicam UV-Visible Spectrometry (Helios, United Kingdom). Normal and treated blood samples 159 had been tested at the same condition (Brown, 1993).

161 follow:

$$
\% \text { Hemolysis }=\frac{\text { O.D. of supernatent }}{\text { O.D. supernatant No } 14} \times 100
$$
supernatant No 14 is the O.D. of $0.000 \mathrm{NaCl}$ concentrations which represents $100 \%$ hemolysis.

Blood films were stained with Leishman stain for 5 min then washed with water for 166 examination. They were scanned and examined using the light microscope (PB362040x) at a 167 magnification power $400 \mathrm{x}$. The images were captured using a digital camera (Yashica, EZ8032, 1688.2 megapixels).

Statistical analysis of the biochemical data was performed by two-way analysis of 170 variance (ANOVA) test and Duncan test using SPSS software program version 17 (SPSS Inc, 171 USA).

\section{Results}

173 UV - Visible spectroscopic analysis results are appeared in figure (1A \&1B). Figure 
174 (1A) represents a simple spectrophotometric registration of UV-visible spectra of different honey 175 and propolis samples at a concentration of $0.1 \mathrm{mg} / \mathrm{ml}$. The first propolis sample spectrum has an 176 absorption band with $\lambda_{\max }$ at $288 \mathrm{~nm}$. The second propolis sample spectrum has a plateau with $177 \lambda_{\max }$ between $270-290 \mathrm{~nm}$. Both propolis samples have an absorption peak at 230, while honey 178 samples did not show any absorption band in this region. At a concentration of $10 \mathrm{mg} / \mathrm{ml}$, honey 179 samples showed spectra with $\lambda_{\max }$ around $280 \mathrm{~nm}$, while the absorption peak at $230 \mathrm{~nm}$ only 180 observed in $\mathrm{H}_{1}$ sample as appeared in Figure (1B).

FTIR spectroscopic analysis shows the spectra pattern of honey in Figure (1C) and of propolis in Figure (1D). The presence of distinct bands in the spectra pattern is considered to be an indication of the presence of certain functional group and the expected compounds are listed

in Table (1). The variations in the intensity of such bands of different samples were listed in 185 Table (2). The correlation coefficient $\left(\mathrm{R}^{2}\right)$ of FTIR band intensity is represented in Table (3).

The total flavonoid and phenols in P1 sample is found to be slightly higher than that P2.

187 H1 sample contains higher content of flavonoid and phenols than $\mathrm{H} 2$ and $\mathrm{H} 3$ samples. Also, it has 188 been found that propolis has greater contents of flavonoid and phenols than honey.

\section{Mineral composition}

Honey and propolis mineral composition was measured using atomic absorption spectroscopy. Six elements (Fe, Mg, Na, K, Ca and $\mathrm{Zn}$ ) were determined in three honey and two 193 propolis samples. The concentrations of these minerals in honey and propolis samples are listed 194 in Table (4). One-way ANOVA test demonstrated a significant difference at $\mathrm{p}<0.05$ in the 
195 content of each mineral amongst propolis and honey samples as well as between different honey

196 or propolis samples.

197

198

199

200

201

202

203

204

205

206

207

208

209

210

211

\section{Biophysical examinations}

\section{Red blood cells membranes studies}

214 Osmotic fragility: Figures $(2 \mathrm{~A}-\mathrm{H})$ shows the effect of $\mathrm{NaCl}$ percent concentrations on osmotic

215 fragility of RBCs membrane and its differentiation.

\section{Biochemical analysis}

The data of serum total protein and albumin were summarized in Tables (5) and (6). A two- way ANOVA test and Duncan test indicated a significant decrease in their levels $(\mathrm{P}<0.05)$ in irradiated rats contrasted to the normal group. Also, treatments with honey, propolis, and their combination induced significant ameliorations compared to irradiated rats. ANOVA showed no significant change between different time intervals post irradiation $(\mathrm{P}>0.05)$ of total protein and albumin and also no significant interaction between factors $(\mathrm{P}>0.05)$.

The data of serum uric acid are summarized in Tables (7). A two- way ANOVA test and Duncan test indicated that uric acid significantly increased $(\mathrm{P}<0.05)$ in rats exposed to $\gamma$ radiation compared with the normal group. Also, different treatments with honey, propolis, and their combination induced significant amelioration compared to irradiated group. The propolis and combination pretreated animal groups showed improvement in serum uric acid levels more than the honey pretreated group. Also, ANOVA demonstrated no significant difference between the level of uric acid at various time intervals post irradiation $(\mathrm{P}>0.05)$ and furthermore no significant interaction between factors $(\mathrm{P}>0.05)$.

Measurements illustrate the variation of the percentage hemolysis as a function of the 
217 percentage of $\mathrm{NaCl}$ concentration in buffer solution for RBCs of different animal subgroups as

218 appeared in Figures (2 A, C, E and G).

To analyze these data, the graphs were differentiated and plotted as a function of the

220 percentage of $\mathrm{NaCl}$ concentration as shown in Figures (2 B, D, F and $\mathrm{H}$ ). From osmotic fragility

221 curves, it is possible to calculate Median Corpuscular Fragility (MCF) which means the $\mathrm{NaCl}$

222 concentration at which $50 \%$ of RBCs are hemolyzed. The points of the differentiation curves

223 were calculated by subtracting each point from the previous one in the hemolysis curve. The

224 width at half maximum $\left(\mathrm{W}_{\mathrm{hmax}}\right)$ of the differentiation curve represents the relative elastic limit of

225 RBCs membrane. The increase of $\mathrm{W}_{\text {hmax }}$ expresses more elasticity of cell membrane. The MCF

226 and $\mathrm{W}_{\mathrm{hmax}}$ values of RBCs from different subgroups were represented in Table (8).

\section{Blood film}

Histological examinations of RBCs by light microscope are shown in Figures (3 A-P).

229 The images of the control samples appear in Figures (3 A-D), for negative control and positive

230 control administered honey propolis and their combination respectively, have normal structures.

231 Figures (3 E-H, and $3 \mathrm{M}-\mathrm{P}$ ) illustrate blood film images of the irradiated and irradiated

232 pretreated animal subgroups at different time intervals $1^{\text {st }}, 7^{\text {th }}$ and $14^{\text {th }}$ day post- irradiation

233 respectively. The results showed a remarkable sticking of RBCs forming aggregation, which

234 persist until the $14^{\text {th }}$ day post- irradiation Figures $(3 \mathrm{E}$, I and M). Oral administration of

235 propolis and the combination diminishes the formation of RBCs aggregation and reduces the

236 damage of irradiation Figures ( $3 \mathrm{G}, \mathrm{K}$ and $\mathrm{O})$ and ( $3 \mathrm{H}$, I and P). Instead, honey recovers RBCs

237 at the $14^{\text {th }}$ day post irradiation Figure $(3 \mathrm{~N})$ while at $1^{\text {st }}$ and $7^{\text {th }}$ days Figures $(3 \mathrm{~F}$ and $\mathrm{J})$ still 
238 have some sort of sticking and deformation.

239 Discussion

UV - Vis spectroscopic investigation affirmed the presence of phenolic compounds in

241 honey and propolis since they exhibit two major absorption bands in UV - Vis region (Moț et al.,

242 2011). The characteristic bands of phenols are a broad band centered around 280-330 nm and a

243 second band at $250 \mathrm{~nm}$ (Yang, al., 2013).

245 isolates and evaluates six antioxidants of propolis at (200-600 nm) (Yang, al., 2013). The spectra

of propolis at a concentration of $0.1 \mathrm{mg} / \mathrm{ml}$ are similar in shape and position to the spectra of honey at a concentration of $10 \mathrm{mg} / \mathrm{ml}$ Figure (1b). These results are in coincidence with intensity and shift in the absorption band might be attributed to the different antioxidant ratios in

255 Vis spectra of samples and total phenolic compounds that were determined by the Folin256 Ciocalteu method (Hamieda et al., 2015). 
260

261

262

263

264

265

266

267

268

269

270

271

272

273

274

275

276

277

278

279

280

281

282

and his coworkers' results (Moț et al., 2011). It is clear that the antioxidant activity of polyphenols does not depend only on the amount of the present compounds but also on their chemical structures (Omene et al., 2012).

The $\mathrm{Fe}, \mathrm{Mg}, \mathrm{Na}, \mathrm{K}, \mathrm{Ca}$ and $\mathrm{Zn}$ are basic elements since they play important roles in the biological systems one of them is their antioxidant activity (Pohl et al., 2012).

The higher minerals concentration in propolis than honey is in coincidence with previously reported data (Grembecka and Szefer 2013; Formicki et al., 2013). Also, honey and propolis samples differ in their mineral constituents depending on the resources in the soil and kind of plants from which the bees took nectar (Shah et al., 2014). These elements do many biological functions since they act as coenzymes and participate in other processes like Redox one (KurekGórecka et al., 2013).

The biochemical analysis of serum total protein is relatively important in assessing the health state of mammals (Vasile et al., 2009). The decrease of total protein post irradiation might be due to the disturbances of the vital biological processes or because of progress in the penetrability of the liver, kidney and other tissues resulting in leakage of protein via the kidney (Muhammad et al., 2015). The decline in the level of albumin concentration could be due to enhanced degradation as well as enhanced loss of albumin through the gastrointestinal tract (Shabon, 2005). Moreover, the extensive damage to the lymphoid organs following $\gamma$ - irradiation was probably related to the drop in serum globulin levels (Moulder et al., 2004). Earlier investigations by Wheeler and Bernard (1994) have reported that irradiation leads to proteinuria, which is associated with low serum total protein and albumin. An improvement in the levels of serum total proteins and albumin in the pretreated groups with propolis and combination maintain their levels near the normal level at the different time intervals. The pretreatment with 
283 honey only shows slight improvement. The effect of pretreatment with propolis is in harmony with Saleh (2012) who reported that propolis significantly improved the total protein content of the liver and kidney and indicated more profound therapeutic effects. group is supported by other works (Ferreira-Leach and Hill, 2001; Saleh, 2012). Uric acid is the end product of the purine metabolism and is normally eliminated by the kidney in urine. Excess uric acid may be a side effect of some cancer treatments and may lead to a condition called tumor lysis syndrome (Crohns et al., 2009). The excess uric acid forms crystals which may 291 deposit in the tiny tubes of the kidney and cause acute kidney damage, leading ultimately to 292 kidney failure (Abd elhalim and Moussa, 2013). This result might be ascribed to the hindrance 293 of glomerular selective properties caused by irradiation (Berry et al., 2001).

The mechanism by which the natural product honey and propolis anticipate renal oxidative stress may incorporate several mechanisms. One of them is the induction of 296 glutathione GSH synthesis which is consumed when bind to free radicals. Others are by a 297 scavenger effect of antioxidants phenols and flavonoids (naringenin, pinostrombin and galangin) 298 found in honey and propolis to the electrons of ROS. This effect could have accumulated in the 299 cells of the proximal convoluted tubules of the kidney where propolis was reported to be 300 collected and secreted (Saleh et al., 2013). Instead of ROS, their free electrons will be captured 301 with the antioxidant (Newairy, et al., 2009). So there must be a massive concern to clarify the 302 clinical role of the propolis. 
305 of the osmotic fragility curves towards the higher $\mathrm{NaCl}$ concentration. Also, the reduction in

$306 \mathrm{~W}_{\text {hmax }}$ is an evidence of decreasing the flexibility of RBCs. This result is in coincidence with

307 Selim and his coworkers (Selim et al., 2009). It is interesting to confirm that these changes in

308 osmotic fragility can be omitted by pretreating with honey, propolis, and their combination.

The increase in the osmotic fragility may be attributed to some changes in the properties of the RBCs membrane. Ionizing radiation causes a disturbance in energy metabolism, disorganization of lipoprotein structure of biological membranes, peroxidation of membrane

312 lipids and inactivation of various bound enzymes $(\mathrm{Na}+, \mathrm{K}+$, and $\mathrm{Mg}+)$ ATPase. It has also been

313 suggested that radiation induces perturbation in $\mathrm{Na}+$ and $\mathrm{K}+$ transport system which is connected

314 with oxidation of membrane protein sulfhydryl groups (Jóźwiak and Helszer 1981).

315 Modification in the physical condition of the membrane proteins may lead to change in the

316 permeability of the RBCs membrane. Some proteins of the cell membrane act as pores (ion

317 channels) through which the aqueous solutions carried inside the cell (Hemida et al., 2011).

membrane damage were observed. This observation could be attributed to the presence of some coenzyme minerals such as $\mathrm{Zn}$ for superoxide dismutase and Fe for catalase. Both enzymes

321 protect the cell membrane from oxidative damage. Since propolis contains both elements, it 322 promotes the formation of the dismutase and catalase and as a consequence decreases the 323 hemolysis. Additionally, Potassium is the principle cation in intracellular fluid and functions in 324 the regulation of the osmotic pressure and co-enzyme of $\mathrm{Na}+\mathrm{K}+$ ATPase (Achikanu et al., 2013; 325 Shah, et al., 2014). It was found that protective effect of propolis on RBCs membrane was 326 related to the higher phenolic content of propolis (Moreira et al., 2011; Valente et al., 2011). 
327 These results mean that propolis act as a powerful antioxidant compound which prevents the

328 oxidative damage of lipoproteins of the cell membrane (Yousif et al., 2012).

RBCs are well known that they are large cells having a biconcave structure which is naturally flexible and bendable (El-marakby et al., 2013). They do not stick together as a result of the Coulomb repulsive forces between the positive electrostatic charges on their outer surface membranes. The electrostatic charges are formed on the surface of the normal healthy RBCs subsequently of the $\mathrm{K}$ ion pump which forms the resting potential across cellular membranes (Hemida et al., 2012). RBCs cell membranes are particularly sensitive to the effects of irradiation. The sticking of several cells together after irradiation is due to the oxidative damage of the free radicals. They destruct the processes within both layers of RBCs membrane and that

337 alters the membrane structure and function (El-marakby et al., 2013). Also, the sticking can be 338 attributed to the changes in the packing properties of the phospholipid bilayer and 339 macromolecules forming the cellular membrane. This will cause changes in the membrane 340 permeability to ion transport and the liquid crystalline phase of the membrane will change.

341 Therefore, one may state that changes in the membrane permeability will result in the change of 342 the membrane bioelectric potential and surface electrostatic charges (Hemida et al., 2012). The 343 loss or decrease of the surface electrostatic charges on the cellular membrane will deteriorate the 344 repulsive forces between adjacent RBCs membranes and cause the sticking. Moreover, the 345 oxidation of membrane proteins leads to red cell vesiculation (Moreira et al., 2011). It is noticed 346 that pretreating of the animals with honey decreases the sticking of cells and reaching mostly to 347 normal shape by propolis and their combination. This is because the hydroxyl groups of the 348 phenolic and flavonoids compounds have anti-lipid peroxidant and rheologically protecting 349 against oxidative stress (de Kok et al., 2010). 


\section{Conclusion}

351 The administration of natural antioxidants such as honey and propolis mixture mitigates $\gamma$ -

352 induced oxidative stress in rat blood.

353 UV absorption spectra and dielectric measurement were found to be good tools to support the 354 data given by biochemical analysis, such as total proteins. The obtained data indicated that honey 355 and propolis mixture display an in vivo antioxidant activity, which is evidenced experimentally 356 by ameliorating the osmotic fragility, sticking and aggregation of red blood cell as well as serum 357 total protein and albumin.

358 Further investigations are required to elucidate the mechanisms of propolis and honey actions.

\section{Declaration of interest}

361 The authors declare that there are no conflicts of interest.

\section{Captions of figures}

363 Figure (1): Absorption spectra of flavonoid (A) UV-Vis of different honey and propolis samples 364 at concentration $0.1 \mathrm{mg} / \mathrm{ml}$ and (B) UV-Vis of different honey samples at concentration $10 \mathrm{mg} /$ $365 \mathrm{ml}(\mathrm{C})$ FTIR spectrum pattern of honey, (D) FTIR spectrum pattern of propolis.

366 Figure (2): (2 A and B) RBCs of control (A) Osmotic fragility curves and (B) Differentiation

367 curves. (2 C and D) RBCs of $1^{\text {st }}$ day post- irradiation (C) Osmotic fragility curves and (D) 368 Differentiation curves (E and F) RBCs of $7^{\text {th }}$ day post- irradiation (E) Osmotic fragility curves 369 and (F) Differentiation curves (2 G and H) RBCs of $14^{\text {th }}$ day post- irradiation (G) Osmotic 370 fragility curves and $(\mathrm{H})$ Differentiation curves. 
371

372

373

374

375

376

377

378

379

380

381

382

383

384

385

386

387

Figure (3 A-P): Microscopic blood film observations of different animal groups RBCs (400X) and (96DPI). (3 A-D) Microscopic blood film observations of controls (A) Negative control rats, (B) Control rats administered honey, (C) Control rats administered propolis (D) Control rats administered combination. ( 3 E-H) Microscopic blood film observations of $1^{\text {st }}$-day post irradiation animal group; (E) irradiated (f) irradiated + honey $(\mathrm{G})$ irradiated + propolis $(\mathrm{H})$ irradiated + combination. (3 I-L) Microscopic blood film observations of $7^{\text {th }}$ day post irradiation animal group; (I) irradiated $(\mathrm{J})$ irradiated + honey $(\mathrm{K})$ irradiated + propolis $(\mathrm{L})$ irradiated + combination. (3 M-P) Microscopic blood film observations of $14^{\text {th }}$ day post irradiation animal group; (M) irradiated $(\mathrm{N})$ irradiated + honey $(\mathrm{O})$ irradiated + propolis $(\mathrm{P})$ irradiated + combination.

\section{References}

Abd elhalim, M. A. K., \& Moussa, S. A. A. (2013). The biochemical changes in rats' blood serum levels exposed to different gamma radiation doses. African Journal of Pharmacy and Pharmacology, 7(15), 785-792.

Achikanu, C. E., Eze-Steven, P. E., Ude, C. M., \& Ugwuokolie, O. C. (2013). Determination of the vitamin and mineral composition of common leafy vegetables in south eastern Nigeria. Int. J. Curr. Microbiol. App. Sci. 2(11), 347- 353.

Ali, F.H., Kassem, G. M. and Atta-Alla, O. A. (2010). Propolis as a natural decontaminant and antioxidant in fresh oriental sausage, Vet. Ital. 46, 167-172.

Ali, I. H., Daoud, A. S., \& Shareef, A. Y. (2012). Physical properties and chemical analysis of Iraqi propolis. Tikrit Journal of Pure Science, 17(2), 26-31. 
Almeida, I. M., Barreira, Oliveira, J. C., \& Ferreira, I. C. (2011). Dietary antioxidant supplements: benefits of their combined use. Food and Chemical Toxicology, 49(12), 32323237.

Berry, C., Brosnan, M. J., Fennell, J., Hamilton, C. A., \& Dominiczak, A. F. (2001). hypertension, 10(2), 247-255.

Bhram,D. and Trinder, P. (1972). An improved colour reagent for the determination of blood glucose by the oxidase system. Analyst,1972,97,1425.

Birben, E., Sahiner, U. M., Sackesen, C., Erzurum, S. and Kalayci, O. (2012). diffusion, agar dilution, broth microdilution and time-kill methodology. J. Appl. $405 \quad$ Microbiol.108, 1534-1543. e0183137. 

cancer radiotherapy. Free radical research, 43(7), 646-657. antigenotoxic properties of vegetables and dietary phytochemicals: the value of genomics biomarkers in molecular epidemiology. Molecular nutrition \& food research, 54(2), 208-217. radiation, Journal of radiation research and applied sciences, ( 6), 2 , 21-30. Ecotoxicology and Environmental Safety, 66(2), 278- 286.

Ferreira-Leach, A. M. R., \& Hill, E. M. (2001). Bioconcentration and distribution of 4-tertenvironmental research, 51(1), 75-89.

427 Formicki, G., Gren, A., Stawaez, R., Zysk, B., \& Gal, A. (2013). Metal content in honey, 428 propolis, wax, and bee Pollen and implications for metal pollution monitoring. Pol. J. Environ. Stud. 22, 99-106. 
Glender, S. (1984). Proteins. In: Clinical Chemistry: Theory, Analysis and Correlation, Kaplan, L.A. and A.J. Pesce (Eds.). Mosby CV. Elsevier, Toranto. 1268-1327. by means of the biuret reaction. J. Boil. Chem. 177,751-766.

Grembecka, M., \& Szefer, P. (2013). Evaluation of honeys and bee products quality based assessment, 185(5), 4033-4047. (2015). Evaluation of radioprotective effects of some bee products and its flavonoid constituents: in vivo study on male rats. Rom. J. Biopys. 25(1), 13-34. by gamma irradiation. Rom. J. Biopys. 22(3-4), 221-234. Biophys. 21(4), 317-329.

Hosseinimehr, S. J. (2010). Flavonoids and genomic instability induced by ionizing radiation. Drug Discovery Today, 15(21), 907-918. 
Jóźwiak, Z., \& Helszer, Z. (1981). Participation of free oxygen radicals in damage of porcine erythrocytes. Radiation Res. 88(1), 11-19.

Khan, F., Garg, V. K., Singh, A. K., Kumar, T. (2018). Role of free radicals and certain antioxidants in the management of huntington's disease: a review. J. Analytical \& Pharmaceutical Res. 7(4), 386- 392.

Khanal, B., Baliga, M. and Uppal, N. (2010). Effect of topical honey on limitation of radiation-induced oral mucositis: an intervention study, Int. J. Oral Maxillofac. Surg. 2010, $39,1181-1185$. Oxid. Med. Cell. Longev. 2018, 7074209. antioxidant flavonoids in Sudanese honey samples by solid phase extraction and high performance liquid chromatography. Journal of Chemistry, 6(S1), S429-S437.

467 Romanian propolis research. Evidence-Based Complementary and Alternative Medicine, 2013. between polyphenolic profile and antioxidant activity of propolis from Transylvania. 
Moreira, L. L., Dias, T., Dias, L. G., Rogão, M., Da Silva, J. P., \& Estevinho, L. M. (2011). Propolis influence on erythrocyte membrane disorder (hereditary spherocytosis): A first approach. Food and Chemical Toxicology, 49(2), 520- 526.

Moreira, L.L., Dias,T., Dias, L. G., Rogao, M., Silva, J. P., Estevinho, L. M. (2011). Propolis influence on erythrocyte membrane disorder (hereditary spherocytosis): A first approach. Food Chem. Toxicol. 49, 520-526.

Moț, A. C., Silaghi-Dumitrescu, R., \& Sârbu, C. (2011). Rapid and effective evaluation of the antioxidant capacity of propolis extracts using DPPH bleaching kinetic profiles, FT- IR and UV-VIS spectroscopic data. Journal of Food Composition and Analysis, 24(4), 516-522.

Moulder, J. E., Fish, B. L., \& Cohen, E. P. (2004). Impact of angiotensin II type 2 receptor blockade on experimental radiation nephropathy. Radiation Res. 161(3), 312-317.

Muhammad, M. M. A., Mouchira, M., \& Naglaa, R. A. (2015). Physiological effects of Bee Venom and Propolis on irradiated Albino rats. Danish Journal of Agriculture and Animal Sciences,11-21.

Newairy, A. S. A., Salama, A. F., Hussien, H. M., \& Yousef, M. I. (2009). Propolis alleviates aluminum-induced lipid peroxidation and biochemical parameters in male rats. Food and Chemical Toxicology, 47(6), 1093-1098.

Nunes, L. C., Galindo, A. B., Lustosa, S. R., Brasileiro, M. T., Do Egito, A. A., Freitas, R. M., Randau, K.P. Rolim Neto, P. J. (2013). Influence of seasonal variation on antioxidant and total phenol activity of red propolis extracts. Adv. Studies Biol. 5, 119-133. 

from propolis, a honeybee product, inhibits growth of breast cancer stem cells. Investigational New Drugs, 30(4), 1279-1288.

495

Orsolic, N. (2010). A review of propolis antitumor action in vivo and in vitro, J. Api Prod. Api. Med. Sci. 2, 1- 20.

Pohl, P., Stecka, H., Sergiel, I., \& Jamroz, P. (2012). Different aspects of the elemental analysis of honey by flame atomic absorption and emission spectrometry: a review. Food Analytical Methods, 5(4), 737-751.

Poljsak, B., Šuput, D. and Milisav, I. (2013). Achieving the Balance between ROS and 956792.

Re, R., Pellegrini, N., Proteggente, A., Pannala, A., M. Yang, M. and Evans, C. R.( 1999). Antioxidant activity applying an improved ABTS radical cation decolorization assay, Free Radic. Biol. Med. 26, 1231-1237.

507 Research and Development of Radioprotective Agents: A Mini-Review. International $508 \quad$ Journal of Radiology 4(2-3), 128-138.

509 Saleh, E. M. (2013). Antioxidant effect of aqueous extract of propolis on hepatotoxicity 510 induced by octylphenol in male rats. Acta Toxicol. Argent, 20(2), 68-81. 

immune changes in wistar rats. American Journal of Biochemistry \& Biotechnology, 9(2), 162. gamma radiation on some biophysical properties of red blood cell membrane. Romanian $J$ Biophys, 19, 171-185.

Shabon, M. H. (2005). Radioprotective effects of soya and garlic oils in irradiated male rats. Isotope Radiation Research, 37, 1525 - 1534. from different Environments. Journal of Food and Nutrition Research, 2(9), 532-538. schidigera and Quillaja saponaria on DNA damage, protein oxidation, lipid peroxidation, and some biochemical parameters in streptozotocin-induced diabetic rats. Journal of Diabetes and its Complications, 22(5), 348-356.

Stan, L. (2012). Propolis commercial tinctures-phenolics and anti-oxidant activity. Agricult. Pract. Sci. J. 83,(3-4). Comprehensive Reviews in Food Science and Food Safety, 15, 720- 738. 

Chemical Toxicology, 49(1), 86-92. fractions in simultaneous exposure to gamma radiation and hyperbarism. Romanian Reports in Physics, 61(1), 121-128. Ysabal Garcia, (2010). Bioactive indicators related to bioelements of eight unifloral honeys, Arch. Latinoam. Nutr. 60, 405-410.7

Wheeler, D. C., \& Bernard, D. B. (1994). Lipid abnormalities in the nephrotic syndrome: causes, consequences, and treatment. Am. J. Kidney dis. 23(3), 331-346. activator of antioxidant enzymes. Postepy Hig. Med. Dosw. 70(0),1483-1498. Pharmaceutical Res.12(5): 771-776. regarding the antioxidant effects of the flavonoids on human erythrocytes. Natural Sci. 2012. regarding the antioxidant effects of the flavonoids on human erythrocytes. Natural Sc. (4) 9, 
Table (1): Distinct bands of honey and propolis in FTIR spectra

\begin{tabular}{|c|c|c|}
\hline Bands $\left(\mathrm{cm}^{-1}\right)$ & Functional group & expected compounds \\
\hline $3330-3373$ & $\mathrm{C}-\mathrm{H}$ aromatics, $\mathrm{O}-\mathrm{H}$ & $\begin{array}{c}\text { Phenolic, its esters, } \\
\text { flavonoids }\end{array}$ \\
\hline 2933 & $\mathrm{C}-\mathrm{H}$ & $\begin{array}{c}\text { Flavonoids, aromatic } \\
\text { ring }\end{array}$ \\
\hline 2853 & $\mathrm{C}-\mathrm{O}, \mathrm{C}-\mathrm{H}$ aromatics & $\begin{array}{l}\text { Phenolic, flavonoids, } \\
\text { aromatic ring }\end{array}$ \\
\hline 1630 & $\mathrm{C}=\mathrm{O}, \mathrm{C}=\mathrm{C}, \mathrm{N}-\mathrm{H}$ & Flavonoids, amino acids \\
\hline 1450 & $\mathrm{C}-\mathrm{H}$, aromatic $\mathrm{CH}_{3}, \mathrm{CH}_{2}$ & $\begin{array}{c}\text { Flavonoids, aromatic } \\
\text { ring }\end{array}$ \\
\hline 1260 & $\mathrm{C}-\mathrm{C}$ stretch & Carbohydrate structure \\
\hline 1160 & $\mathrm{C}-\mathrm{O}, \mathrm{C}-\mathrm{OH}$ & $\begin{array}{c}\text { fatty acids, steroids, } \\
\text { carboxylic acids }\end{array}$ \\
\hline 1043 & $\mathrm{C}-\mathrm{O}$ stretch in $\mathrm{C}-\mathrm{OH}$ group & Carbohydrate structure \\
\hline 920 & $\mathrm{C}-\mathrm{H}$ bending & Carbohydrate structure \\
\hline
\end{tabular}

Table (2): The variation of bands intensity in FTIR spectra 
566

567

568

569

570

571

572

573

571

\begin{tabular}{|c|c|c|c|c|}
\hline \multirow{2}{*}{ Sample } & H2 & H3 & P1 & P2 \\
\cline { 2 - 5 } Band $\left(\mathbf{c m}^{-1}\right)$ & \multicolumn{4}{|c|}{ Intensity } \\
\hline 3373 & \multicolumn{4}{|c|}{} \\
\hline 2933 & 27.55 & 26.80 & 41.65 & 29.45 \\
\hline 2853 & & & 48.38 & 34.49 \\
\hline 1630 & 39.69 & 38.47 & 43.58 & 30.85 \\
\hline 1450 & 30.28 & 25.29 & 49.37 & 34.78 \\
\hline 1260 & 34.15 & 32.72 & 49.74 & 35.01 \\
\hline 1160 & & & 47.55 & 34.76 \\
\hline 1043 & 4.16 & 1.70 & 55.20 & 46.66 \\
\hline
\end{tabular}

Table (3): C orrelation coefficient of FTIR bands intensity

\begin{tabular}{|c|c|}
\hline Bands $\left(\mathbf{c m}^{-\mathbf{1}}\right)$ & Correlation coefficient $\left(\mathbf{R}^{\mathbf{}}\right)$ \\
\hline $3330-3373$ & 0.9955 well correlation \\
\hline 2933 & 0.9831 well correlation \\
\hline 1630 & -1.377 negative correlation \\
\hline 1450 & 0.498 poor correlation \\
\hline 1260 & 0.7065 poor correlation \\
\hline 1160 & 0.9594 well correlation \\
\hline 1043 & 0.9916 well correlation \\
\hline
\end{tabular}

Table (4): Concentration of the trace elements studied in honeys and propolis in mg/100g dry weight.

\begin{tabular}{|c|c|c|c|c|c|}
\hline \multirow{2}{*}{ Mineral } & \multicolumn{5}{|c|}{ Sample } \\
\cline { 2 - 6 } & $\mathbf{H 1}$ & $\mathbf{H} 2$ & $\mathbf{H} 3$ & $\mathbf{P 1}$ & $\mathbf{P 2}$ \\
\hline $\mathbf{F e}$ & $1.97 \pm 0.3^{\mathrm{d}}$ & $1.51 \pm 0.8^{\mathrm{e}}$ & $3.58 \pm 0.6^{\mathrm{C}}$ & $37.98 \pm 2.4^{\mathrm{a}}$ & $28.78 \pm 1.2^{\mathrm{b}}$ \\
\hline $\mathbf{M g}$ & $7.78 \pm 1.6^{\mathrm{C}}$ & $4.04 \pm 2.9^{\mathrm{C}}$ & $7.57 \pm 2.4^{\mathrm{c}}$ & $153.24 \pm 9.1^{\mathrm{a}}$ & $41.60 \pm 1.7^{\mathrm{b}}$ \\
\hline $\mathbf{N a}$ & $3.60 \pm 0.4^{\mathrm{b}}$ & $1.89 \pm 0.4^{\mathrm{b}}$ & $3.77 \pm 0.7^{\mathrm{b}}$ & $18.80 \pm 1.9^{\mathrm{a}}$ & $17.96 \pm 1.1^{\mathrm{a}}$ \\
\hline $\mathbf{K}$ & $17.63 \pm 0.4^{\mathrm{C}}$ & $14.5 \pm 0.8^{\mathrm{cd}}$ & $9.15 \pm 1.6^{\mathrm{d}}$ & $105.82 \pm 7.4^{\mathrm{a}}$ & $75.37 \pm 2.4^{\mathrm{b}}$ \\
\hline
\end{tabular}




\begin{tabular}{|c|c|c|c|c|c|}
\hline $\mathrm{Ca}$ & $35.56 \pm 1.9^{\mathrm{cd}}$ & $39.10 \pm 1.7^{\mathrm{c}}$ & $27.65 \pm 1.4^{\mathrm{d}}$ & $155.30 \pm 6.6^{\mathrm{a}}$ & $76.54 \pm 1.2^{\mathrm{b}}$ \\
\hline $\mathrm{Zn}$ & $0.62 \pm 0.2^{\mathrm{c}}$ & $0.11 \pm 0.1^{\mathrm{c}}$ & $0.13 \pm 0.1^{\mathrm{c}}$ & $24.63 \pm 1.2^{\mathrm{a}}$ & $13.43 \pm 0.5^{\mathrm{b}}$ \\
\hline
\end{tabular}

574

575

576

577

578

579

580

581

582

583

584

585

Table (5): Total serum protein levels in irradiated rats and those treated with honey, propolis separately and combined pre $\gamma$-irradiation.

\begin{tabular}{|c|c|c|c|}
\hline \multirow{2}{*}{ Treatment } & \multicolumn{3}{|c|}{ Days after $\gamma$ - irradiation } \\
\cline { 2 - 5 } & $1^{\text {st }}$ & $7^{\text {th }}$ & $1^{\text {th }}$ \\
\hline Normal & $5.44 \pm 0.26^{\mathrm{a}}$ & $5.50 \pm 0.87^{\mathrm{a}}$ & $5.34 \pm 0.85^{\mathrm{a}}$ \\
\hline Honey & $6.00 \pm 0.30^{\mathrm{a}}$ & $5.44 \pm 0.14^{\mathrm{a}}$ & $4.65 \pm 0.71^{\mathrm{a}}$ \\
\hline Propolis & $4.81 \pm 0.74^{\mathrm{ab}}$ & $5.30 \pm 0.23^{\mathrm{ab}}$ & $4.60 \pm 0.68^{\mathrm{ab}}$ \\
\hline Combined & $5.00 \pm 0.16^{\mathrm{ab}}$ & $5.23 \pm 0.17^{\mathrm{ab}}$ & $5.04 \pm 0.34^{\mathrm{ab}}$ \\
\hline $\begin{array}{c}\text { Irradiated } \\
\text { honey }\end{array}$ & $3.78 \pm 0.34^{\mathrm{c}}$ & $3.06 \pm 0.49^{\mathrm{c}}$ & $3.34 \pm 0.31^{\mathrm{c}}$ \\
\hline $\begin{array}{c}\text { Irradiated }+ \\
\text { prpolis }\end{array}$ & $5.97 \pm 0.78^{\mathrm{b}}$ & $4.30 \pm 0.55^{\mathrm{b}}$ & $4.21 \pm 0.81^{\mathrm{b}}$ \\
\hline $\begin{array}{c}\text { Irradiated }+ \\
\text { combined }\end{array}$ & $5.44 \pm 0.53^{\mathrm{a}}$ & $5.37 \pm 0.35^{\mathrm{a}}$ & $5.24 \pm 0.82^{\mathrm{ab}}$ \\
\hline
\end{tabular}

Data expressed as mean $\pm \mathrm{SD}$, mg/100g of dried sample, $n=3$

* Significant different at $\mathbf{p}<\mathbf{0 . 0 5}$. Duncan test results are expressed as letters (a, b, c, d and e). Values with different superscript letters are significantly differ. Values with same letters indicate no significant difference between samples. For each element separately (each row).

\section{Data expressed as mean $\pm \mathrm{SE}, \mathrm{n}=\mathbf{1 0}$}

Duncan test results are expressed as letters ( $a$ and $b$ ). Values with different superscript letters are significantly different. Values with same letters indicate no significant difference between samples for each time separately (each coulomb). 
Table (6): Serum albumin levels in irradiated rats and treated with honey, propolis separately and combined pre $\gamma$ - irradiation.

\begin{tabular}{|c|c|c|c|}
\hline \multirow{2}{*}{ Treatment } & \multicolumn{3}{|c|}{ Days after $\boldsymbol{~}$ - irradiation } \\
\cline { 2 - 4 } & $1^{\text {st }}$ & $7^{\text {th }}$ & $1^{\text {th }}$ \\
\hline Normal & $3.1 \pm 0.102^{\mathrm{a}}$ & $2.88 \pm 0.44^{\mathrm{a}}$ & $2.94 \pm 0.44^{\mathrm{a}}$ \\
\hline Honey & $3.42 \pm 0.21^{\mathrm{a}}$ & $3.17 \pm 0.08^{\mathrm{a}}$ & $2.66 \pm 0.42^{\mathrm{a}}$ \\
\hline Propolis & $3.23 \pm 0.39^{\mathrm{a}}$ & $3.00 \pm 0.08^{\mathrm{a}}$ & $3.21 \pm .42^{\mathrm{a}}$ \\
\hline Combined & $3.2 \pm 0.44^{\mathrm{a}}$ & $3.1 \pm 0.39^{\mathrm{a}}$ & $3.2 \pm 0.197^{\mathrm{a}}$ \\
\hline Irradiated & $2.54 \pm 0.13^{\mathrm{b}}$ & $1.96 \pm 0.04^{\mathrm{b}}$ & $1.68 \pm 0.12^{\mathrm{b}}$ \\
\hline $\begin{array}{c}\text { Irradiated }+ \\
\text { honey }\end{array}$ & $3 \pm 0.10^{\mathrm{a}}$ & $2.93 \pm 0.44^{\mathrm{a}}$ & $2.95 \pm 0.46^{\mathrm{a}}$ \\
\hline $\begin{array}{c}\text { Irradiated }+ \\
\text { prpolis }\end{array}$ & $3.19 \pm 0.11^{\mathrm{a}}$ & $2.90 \pm 0.40^{\mathrm{a}}$ & $3.50 \pm 0.11^{\mathrm{a}}$ \\
\hline $\begin{array}{c}\text { Irradiated }+ \\
\text { combined }\end{array}$ & $2.82 \pm 0.43^{\mathrm{a}}$ & $2.99 \pm 0.11^{\mathrm{a}}$ & $2.95 \pm 0.43^{\mathrm{a}}$ \\
\hline
\end{tabular}

Table (7): Serum uric acid levels in irradiated rats and those treated with honey, propolis separately and combined pre $\gamma$ - irradiation

\begin{tabular}{|c|c|c|c|}
\hline \multirow{2}{*}{ Treatment } & \multicolumn{3}{|c|}{ Days after $\gamma$ - irradiation } \\
\cline { 2 - 4 } & $1^{\text {st }}$ & $7^{\text {th }}$ & $14^{\text {th }}$ \\
\hline
\end{tabular}




\begin{tabular}{|c|c|c|c|}
\hline Normal & $1.43 \pm 0.04^{\mathrm{b}}$ & $1.32 \pm 0.03^{\mathrm{b}}$ & $1.48 \pm 0.08^{\mathrm{b}}$ \\
\hline Honey & $1.38 \pm 0.03^{\mathrm{b}}$ & $1.51 \pm 0.031^{\mathrm{b}}$ & $1.59 \pm 0.05^{\mathrm{b}}$ \\
\hline Propolis & $1.46 \pm 0.09^{\mathrm{b}}$ & $1.56 \pm 0.03^{\mathrm{b}}$ & $1.38 \pm 0.11^{\mathrm{b}}$ \\
\hline Combined & $1.51 \pm 0.11^{\mathrm{b}}$ & $1.43 \pm 0.05^{\mathrm{b}}$ & $1.45 \pm 0.08^{\mathrm{b}}$ \\
\hline Irradiated & $2.28 \pm 0.03^{\mathrm{a}}$ & $3.00 \pm 0.05^{\mathrm{a}}$ & $3.23 \pm 0.19^{\mathrm{a}}$ \\
\hline $\begin{array}{c}\text { Irradiated + } \\
\text { honey }\end{array}$ & $1.41 \pm 0.09^{\mathrm{b}}$ & $1.40 \pm 0.07^{\mathrm{b}}$ & $1.52 \pm 0.06^{\mathrm{b}}$ \\
\hline $\begin{array}{c}\text { Irradiated + } \\
\text { prpolis }\end{array}$ & $1.48 \pm 0.06^{\mathrm{b}}$ & $1.38 \pm 0.04^{\mathrm{b}}$ & $1.38 \pm 0.05^{\mathrm{b}}$ \\
\hline $\begin{array}{c}\text { Irradiated + } \\
\text { combined }\end{array}$ & $1.38 \pm 0.05^{\mathrm{b}}$ & $1.17 \pm 0.04^{\mathrm{b}}$ & $1.15 \pm 0.08^{\mathrm{b}}$ \\
\hline
\end{tabular}

625

Table (8): The values of MCF and Whmax for from different animal subgroups RBCs 626

\begin{tabular}{|c|c|c|}
\hline Group & MCF & Whmax(arbitrary units) \\
\hline \multicolumn{3}{|c|}{ Control group } \\
\hline $\mathbf{N}$ & 0.498 & 0.140 \\
\hline $\mathbf{H}$ & 0.514 & 0.140 \\
\hline $\mathbf{P}$ & 0.498 & 0.139 \\
\hline$C$ & 0.500 & 0.163 \\
\hline \multicolumn{3}{|c|}{$1^{\text {st }}$ day post irradiation } \\
\hline R1d & 0.570 & 0.135 \\
\hline HR1d & 0.520 & 0.139 \\
\hline PR1d & 0.520 & 0.149 \\
\hline CR1d & 0.520 & 0.150 \\
\hline \multicolumn{3}{|c|}{$7^{\text {th }}$ days post irradiation } \\
\hline R7d & 0.560 & 0.130 \\
\hline HR7d & 0.525 & 0.130 \\
\hline PR7d & 0.515 & 0.140 \\
\hline CR7d & 0.498 & 0.150 \\
\hline
\end{tabular}


bioRxiv preprint doi: https://doi.org/10.1101/472233; this version posted November 19, 2018. The copyright holder for this preprint (which was not certified by peer review) is the author/funder. All rights reserved. No reuse allowed without permission.

\begin{tabular}{|c|l|l|}
\hline R14d & 0.530 & 0.132 \\
\hline HR14d & 0.520 & 0.137 \\
\hline PR14d & 0.515 & 0.147 \\
\hline CR14d & 0.500 & 0.150 \\
\hline
\end{tabular}

627 


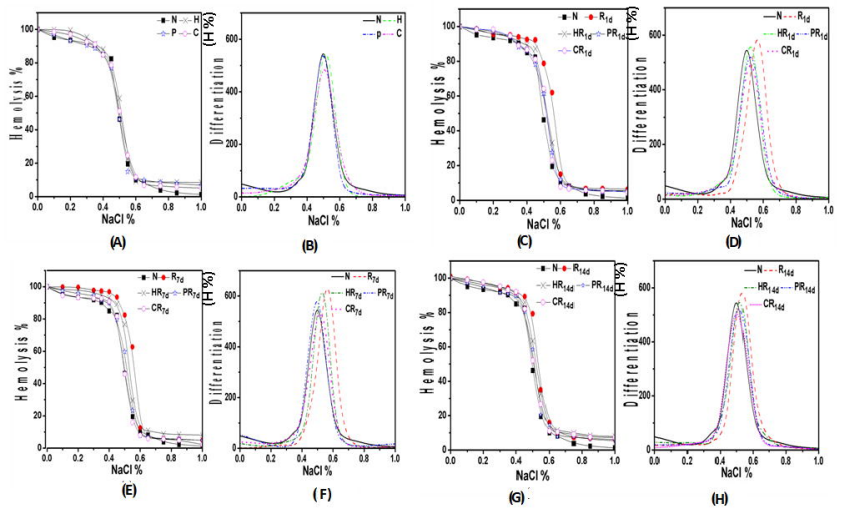




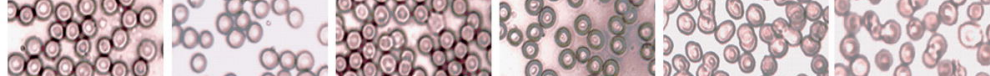
000

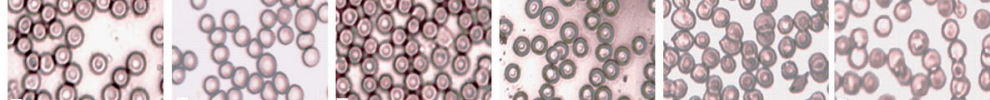

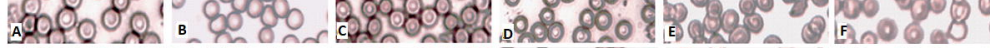

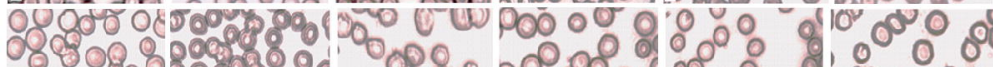

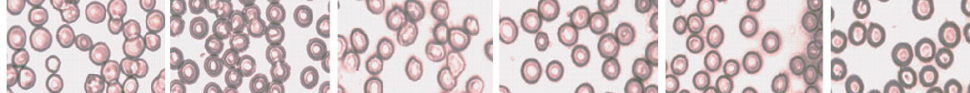

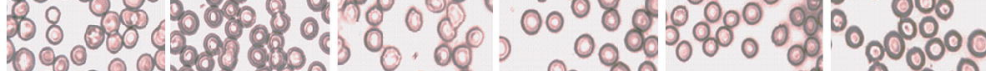

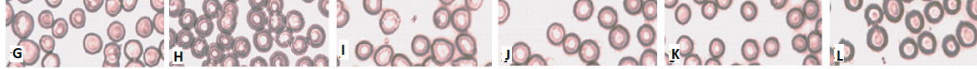

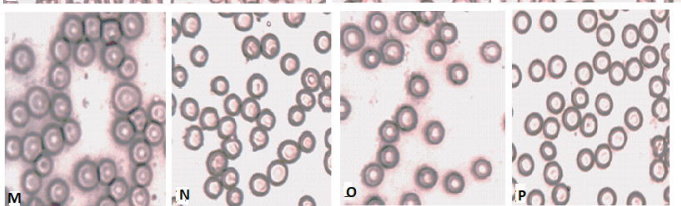

